\title{
Femoral Head Size Does Not Affect Ion Values in Metal-on-Metal Total Hips
}

\author{
Mitchell Bernstein MD, Alan Walsh MD, \\ Alain Petit PhD, David J. Zukor MD, \\ John Antoniou MD, PhD
}

Published online: 21 October 2010

(C) The Association of Bone and Joint Surgeons( 2010

\begin{abstract}
Background Metal-on-metal articulations can release substantial amounts of particles containing cobalt and chromium into the surrounding milieu, causing concern for cellular toxicity and adverse local soft tissue reactions. The diameter of the femoral head has been one of the variables that inversely affects wear of metal-on-metal total hip arthroplasty (THA). The oxidative stress of increased metal ions can be measured with serum markers. It is still controversial if larger femoral head diameters decrease wear rates in patients with metal-on-metal THA and if the increased metal ions alter the body's antioxidant status.
\end{abstract}

Each author certifies that he or she has no commercial associations (eg, consultancies, stock ownership, equity interest, patent/licensing arrangements, etc) that might pose a conflict of interest in connection with the submitted article.

Each author certifies that his or her institution has approved the human protocol for this investigation, that all investigations were conducted in conformity with ethical principles of research, and that informed consent for participation in the study was obtained.

This work was performed at the Division of Orthopaedic Surgery, McGill University, SMBD-Jewish General Hospital, Montreal, QC, Canada.

M. Bernstein, A. Walsh, A. Petit, D. J. Zukor, J. Antoniou Division of Orthopaedic Surgery, McGill University Health Centre, Montreal, QC, Canada

A. Walsh, A. Petit, D. J. Zukor, J. Antoniou

Lady Davis Institute for Medical Research, SMBD-Jewish

General Hospital, Montreal, QC, Canada

J. Antoniou ( $\square)$

Department of Orthopaedics, Chemin de la Côte Ste-Catherine,

Room E-003, SMBD-Jewish General Hospital, 3755, Montreal,

QC H3T 1E2, Canada

e-mail: janton@orl.mcgill.ca
Questions/purposes We therefore (1) determined whole blood metal ions in patients with small $(28 \mathrm{~mm}$ and $36 \mathrm{~mm}$ ) and large (40 $\mathrm{mm}$ and $44 \mathrm{~mm}$ ) diameter femoral heads; (2) measured oxidative stress markers (total antioxidants, nitrotyrosine, and peroxides); and (3) determined whether acetabular version or inclination influenced ion levels.

Methods One hundred four patients were retrospectively studied. We recorded Harris hip scores and UCLA activity scores. All patients were followed at 1 year.

Results The activity scores were similar in the two groups. There was no difference in metal ion levels or oxidative stress markers between patients with small- or large-diameter femoral heads. Acetabular inclination and anteversion had no effect on the metal ion levels.

Conclusions The data suggest there is no difference in ion values in patients with large or small metal-on-metal THA and the increased metal ions do not alter the oxidant status of the patient.

Level of Evidence Level III, retrospective comparative study. See Guidelines for Authors for a complete description of levels of evidence.

\section{Introduction}

Wear-induced osteolysis continues to limit the durability of implants in THA [23]. Active patients require bearings that can sustain prolonged loading cycles to prevent premature implant failure [5, 39, 49]. Increased understanding of tribology from hip-simulator studies and retrieved metalon-metal articulations has led to improved manufacturing of second-generation components [12, 13]. Modern bearings containing cobalt, chromium, and molybdenum alloys are engineered with decreased surface roughness and 
diametric bearing clearances, harder surfaces, and increased sphericity aimed at enhancing the fluid-film thickness to surface roughness ratio (lambda ratio) [12, 51]. This decreases frictional forces [13] and volumetric wear rates compared with conventional metal-on-polyethylene hip arthroplasties and has prevented seizing of the articulations [1, 12, 44].

Although volumetric wear is decreased in metal-onmetal bearings, as a result of the small-sized debris generated, these bearings can release up to 500 times more particles than what occurs in metal-on-polyethylene articulations [21]. Metal ion production is not only a function of wear; bearings can also release ions by passive dissolution and galvanic corrosion. This occurs when different types of metal are in contact, as found in the Morse taper [25, 36]. This may have long-term clinical consequences because these bearings are frequently used in younger patients who are more active and have longer average lifespans. In vitro studies, linking cobalt and chromium ions with inflammation, cytotoxicity, altered lymphocyte concentrations, and irreversible chromosomal damage, have caused concern [11, 17, 30-32, 46]. Cobalt and chromium are unstable transitional metals that generate the formation of reactive oxygen species, increasing the concentration of free radicals in the body and consuming the antioxidants that neutralize them [53].

Clinical and hip simulator studies suggest metallurgy and acetabular component positioning are important factors in the production of metal ions and early failure [40]. Increasing acetabular and femoral modularity [37], acetabular abduction angles above $55^{\circ}$ [7, 19, 29], and smaller femoral head diameters all increase the risk of rim contact, impingement, and edge loading [34]. Ideal fluid-film lubrication (lambda ratio greater than 3) occurs in articulations with identical femoral head and acetabular diameters, minimal clearance, and polar contact [44, 48]. The surface microtopography of metal components contains asperities [12], and perfect spheres with equal diameters cannot be consistently produced. Nevertheless, congruent joints operating at lambda ratios between one and three are feasible with larger femoral head diameters given all other manufacturing parameters are equal [22, 51]. Larger femoral heads above $32 \mathrm{~mm}$ are often used in hip arthroplasty because of the following advantages: (1) increased ROM by increasing the head-neck ratio; (2) decreasing the occurrence of impingement; and (3) decreasing the rates of dislocation $[8,9]$. Several studies report the effects of femoral head diameter on cobalt and chromium ion concentrations $[2,14,16,24,42,54]$ but they contained relatively small patient samples, compared femoral head diameters in hip resurfacings, or included only femoral head diameters of 28 and $36 \mathrm{~mm}$.
We therefore (1) determined whether whole blood metal ion levels differed in patients with small $(28 \mathrm{~mm}$ and $36 \mathrm{~mm}$ ) and large (40 $\mathrm{mm}$ and $44 \mathrm{~mm}$ ) diameter femoral heads after metal-on-metal THA; (2) measured oxidative stress markers (total antioxidants, nitrotyrosine, and peroxides) to determine if the increased metal ions altered the body's oxidant status; and (3) determined whether acetabular version or inclination influenced ion levels.

\section{Patients and Methods}

From July 2007 to August 2008, we prospectively followed 104 patients to determine the effect of femoral head diameter on the concentration of whole blood metal ions. The exclusion criteria of our study were aimed at eliminating confounding variables for increased metal ion analysis including those with severe medical illness limiting mobility, concurrent metal components elsewhere in the body, infection, bilateral hip arthroplasty, and renal insufficiency $[6,33]$. We defined small femoral heads as those with diameters of 28 and $36 \mathrm{~mm}(\mathrm{n}=48)$ and large femoral heads as those having diameters of 40 and $44 \mathrm{~mm}$ $(n=56)$. The groupings were chosen in part to explore the potential advantage of femoral head sizes greater than $36 \mathrm{~mm}$. Because of patient anatomy, we had few patients in the 28-mm group. We therefore required the patients in the 36-mm head group to serve as a comparison. Notably, it has been previously demonstrated that metal ion concentrations at 1 year are similar in patients with either 28- or 36-mm femoral heads [2]. The power calculation was performed based on a statistical power of $80 \%$, an alpha error level of confidence of $5 \%$, and assuming a $10 \%$ to $15 \%$ difference in ion levels between the study groups. Approximately 45 patients would be necessary in each group to observe a significant difference. The mean age in all patients at the time of the hip arthroplasty was 61 years (range, 36-77 years). The mean age was 64 years (range, 41-77 years) and 60 years (range, 36-74 years) in patients with a small- and large-diameter femoral heads, respectively (Table 1). The most common diagnoses in the small femoral head group were osteoarthritis (83\%), developmental dysplasia of the hip (8\%), and avascular necrosis $(6 \%)$, whereas one patient had posttraumatic osteoarthritis after a failed hip pinning. The most common diagnoses in the large femoral head group were osteoarthritis (73\%), avascular necrosis (12\%), revision arthroplasty $(7 \%)$, and developmental dysplasia of the hip (4\%), whereas one patient had osteoarthritis that led to hip fusion and one patient had septic arthritis. The preoperative renal function was normal in all patients as defined with normal preoperative screening serum creatinine (range, 55-110 $\mu \mathrm{mol} / \mathrm{L}$ ). No patients were lost to followup. Before the study, 
Table 1. Patient demographics and comparative activity scores after metal-on-metal THAs

\begin{tabular}{lllll}
\hline Patient characteristics & Preoperative & $\begin{array}{l}\text { Small femoral head } \\
(28 \mathrm{~mm} \text { and 36 mm) }\end{array}$ & $\begin{array}{l}\text { Large femoral head } \\
(40 \mathrm{~mm} \text { and 44 mm) }\end{array}$ & $\begin{array}{l}\mathrm{p} \text { Value } \\
\text { (small versus large) }\end{array}$ \\
\hline Number of patients (male:female) & & $48(6: 42)$ & $56(48: 8)$ & N/A \\
Mean age (range) & & $63.8(41-77)$ & $59.5(36-74)$ & 0.003 \\
Approach (\% posterolateral:posterior) & & $49: 51$ & $25: 75$ & N/A \\
Harris hip score (mean \pm SD) & $43.3 \pm 11.9$ & $84.8 \pm 13.7$ & $86.4 \pm 15.0$ & 0.58 \\
UCLA Activity Score (mean \pm SD) & $3.82 \pm 2.0$ & $6.0 \pm 1.6$ & $6.4 \pm 1.7$ & 0.19 \\
\hline
\end{tabular}

$\mathrm{N} / \mathrm{A}=$ not applicable.

Institutional Review Board approval was obtained. Patients provided informed consent at their 6-week followup before allowing analysis of their blood and clinical data.

Implanted femoral heads were DePuy Ultamet $^{\mathrm{TM}}$ (DePuy, Warsaw, IN) and Metasul (Zimmer, Warsaw, IN). Metasul is a forged, wrought, high-carbon cobalt-chrome alloy component. The radial clearance is $75 \mu \mathrm{m}$ and the surface roughness is less than $0.005 \mu \mathrm{m}$ (manufacturer's data; Zimmer). Ultamet is also a forged, wrought, highcarbon cobalt-chrome alloy; radial clearance ranges from 40 to $80 \mu \mathrm{m}$. The surface roughness is less than or equal to $0.02 \mu \mathrm{m}$ (manufacturer's data; DePuy). Metasul was used for the 28-mm femoral heads, whereas the remaining bearings were Ultamet. The acetabular components in the small and large head groups were similar in design, specifically in coverage arcs.

Three surgeons performed the operations using either a posterior or direct lateral approach to the hip (Table 1). We used either posterior or direct lateral approaches with the patient in the lateral decubitus position. The posterior approach was carried out with a skin incision centered at the greater trochanter, approximately $10 \mathrm{~cm}$ in length. The external rotators were removed from the greater trochanter using electrocautery. A T-shaped posterior capsulotomy was performed. The hip was dislocated posteriorly. After the components were placed, the hip was reduced and taken through the full ROM to ensure there was no impingement or instability. The posterior capsule and external rotators were sewn back to the greater trochanter using nonabsorbable transosseous sutures. The lateral approach was performed through a direct lateral incision. The anterior two-thirds of the gluteus medius, gluteus minimus, and an osteoperiosteal flap were removed from the greater trochanter. The anterior hip capsule was opened in an H-fashion. The femoral head was dislocated anteriorly. The trochanteric flap was reapproximated with transosseous sutures through the greater trochanter.

Patients were evaluated at 6 weeks, 3 months, and annually thereafter. We obtained radiographic, clinical, and metal ion data for all patients at 12 months. Laboratory personnel involved in data analysis were blinded to the study protocol. The Harris hip score (HHS) [28] and the UCLA activity score [56] were used as functional outcome measures. The HHS at 1-year followup increased in both the small- and large-diameter femoral head groups when compared with preoperative values $(\mathrm{p}<0.0001)$ (Table 1). However, no difference in HHS was observed when comparing the small- with the large-diameter femoral head groups $(\mathrm{p}=0.58)$. The UCLA activity score also increased in both the small- and large-diameter femoral head groups at 1 year $(\mathrm{p}<0.0001)$ compared with preoperative values. Similarly, no change was observed when comparing the UCLA activity score between the small- and large-diameter femoral head groups $(\mathrm{p}=0.19)$.

Two of us (AW, MB) measured acetabular inclination and anteversion on AP pelvic digital radiographs. Measurements were performed using the Einzel-BildRoentgen-Analyse software (EBRA; University of Innsbruck, Innsbruck, Austria), an already described and validated method [41].

Cobalt, chromium, and molybdenum ion levels were measured from whole blood and analyzed using inductively coupled plasma-mass spectrometry (SCIEX Elan 6100 DRC ICP-MS system; PerkinElmer Instruments, Norwalk, CT) as previously described [2, 10]. Whole blood, and not serum, was used because it provides a more accurate surrogate for metal ion concentration [15]. Blood samples were collected into Sarstedt Monovette $\mathbb{R}$ tubes for trace metal analysis with 21-G needles also specific for trace metal analysis (Sarstedt, Montreal, Quebec, Canada) and stored at $-80^{\circ} \mathrm{C}$ until ready for dilution and analysis. The biologic reference standard SeroNorm Trace Elements Whole Blood, Level 2 (Sero AS, Billingstad, Norway) was used as a quality control sample.

Metal ions can increase the concentration of free radicals, which subsequently generate products of oxidative stress. For example, the reactive oxygen species superoxide reacts with protein tyrosine residues to increase the concentration of nitrotyrosine. This molecule can then act as a surrogate of oxidative stress in the cell [4]. Similarly, lipids in the cellular membranes are oxidized generating lipid peroxides that increase the total peroxide concentration. 
As the oxidant status increases the levels of total antioxidants, the chemical moieties that consume them are decreased. The total antioxidant status (Oxford Biomedical total antioxidant power kit, Oxford, MI), total peroxide concentration, (Biomedica OxyStat assay; Medicorp, Montreal, Quebec, Canada), and nitrotyrosine levels (BIOXYTECH, Nitrotyrosine-EIA assay; OxisResearch, Portland, OR) were measured from patients' plasma using a previously described technique [2].

The metal ion data and values for nitrotyrosine were asymmetrically distributed and there was variability between the groups. Therefore, the Kruskal-Wallis test was used, which is a nonparametric equivalent of one-way analysis of variance. Total antioxidant and peroxide concentrations were symmetrically distributed and allowed for comparison using analysis of variance (ANOVA) followed by Fisher's protected least significant difference (PLSD). The HHS and UCLA activity scores were also calculated with ANOVA followed by Fisher's PLSD. Correlations between the different parameters were performed using the Spearman's rank correlation coefficient.
Statistical analysis was performed using StatView (SAS Institute, Cary, NC).

\section{Results}

At 1-year followup, the median whole blood levels of cobalt were similar ( $\mathrm{p}=0.42)$ with small- and largediameter femoral heads $(2.34 \mu \mathrm{g} / \mathrm{L}$ and $2.22 \mu \mathrm{g} / \mathrm{L}$, respectively) (Fig 1A). The median concentration of chromium was also similar $(\mathrm{p}=0.29)$ comparing the small and large groups $(0.78 \mu \mathrm{g} / \mathrm{L}$ and $0.51 \mu \mathrm{g} / \mathrm{L}$, respectively) (Fig 1B). There were no differences $(p=0.052)$ in the median whole blood molybdenum concentrations $(1.86 \mu \mathrm{g} / \mathrm{L}$ and $1.59 \mu \mathrm{g} / \mathrm{L}$, respectively) (Fig $1 \mathrm{C}$ ).

The levels of total antioxidants $(\mathrm{p}=0.86)$, nitrotyrosine $(\mathrm{p}=0.22)$, and peroxides $(\mathrm{p}=0.56)$ were similar in patients with small and large head THA (Table 2).

We observed a higher $(\mathrm{p}=0.009)$ mean acetabular inclination in the small femoral head group compared with that of the large femoral head group (mean $45.8^{\circ}$ versus
Fig. 1A-C Metal ions in patients after THA with either small or large femoral head diameters are shown. (A) Whole blood cobalt (Co), (B) chromium $(\mathrm{Cr})$, and $(\mathbf{C})$ molybdenum (Mo) ion concentrations were analyzed at 6 months and 1 year postoperatively. There was no change in metal ion values when comparing head diameters at each interval.
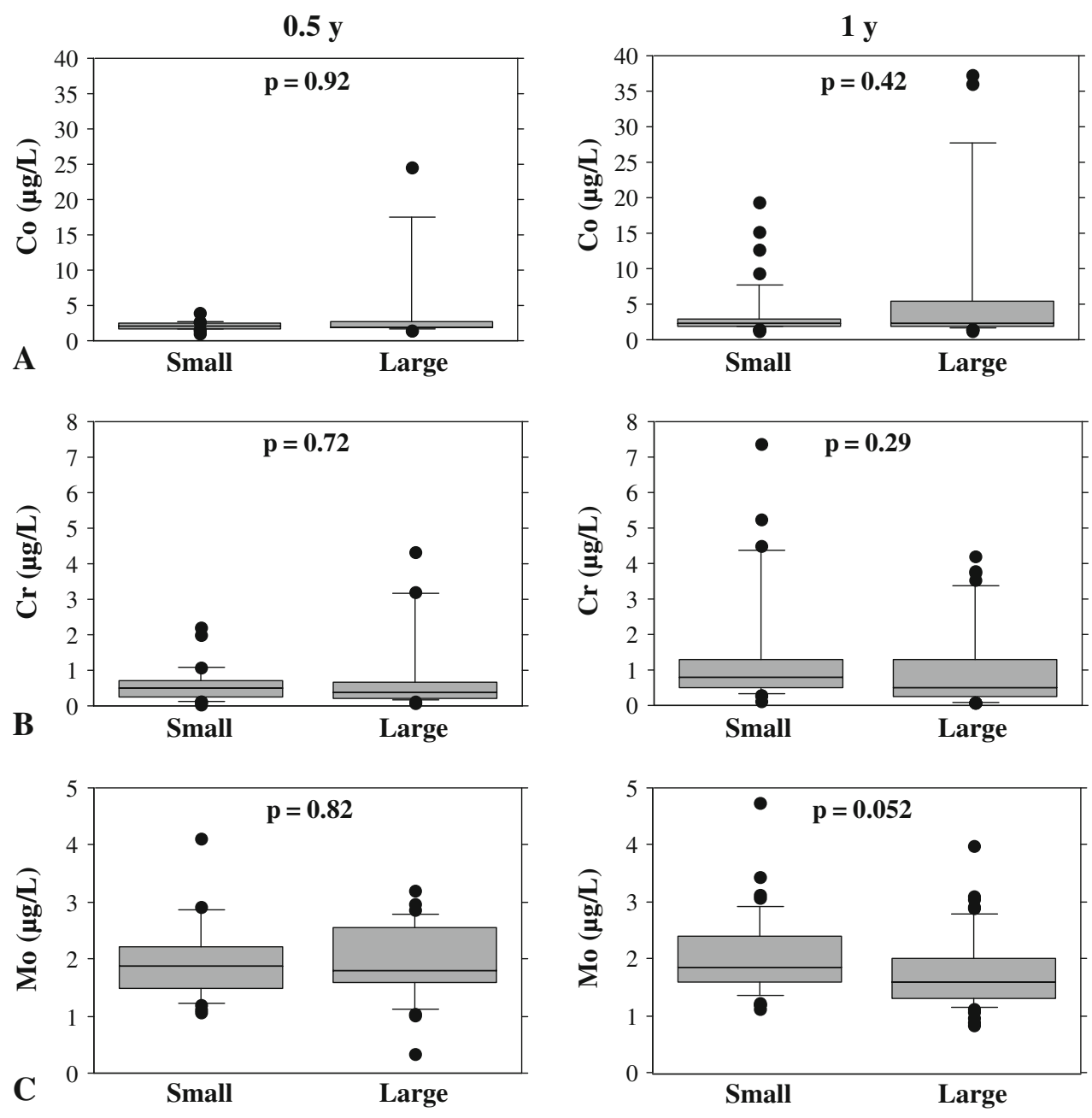
Table 2. Results comparing patients after small- or large-diameter metal-on-metal THA

\begin{tabular}{llll}
\hline Radiographic and metal ion variables & $\begin{array}{l}\text { Small femoral head } \\
(28 \mathrm{~mm} \text { and } 36 \mathrm{~mm})\end{array}$ & $\begin{array}{l}\text { Large femoral head } \\
(40 \mathrm{~mm} \text { and } 44 \mathrm{~mm})\end{array}$ & $\mathrm{p} \mathrm{Value}$ \\
\hline Acetabular anteversion (range)* $^{*}$ & $26(5-47)$ & $20(4-39)$ & 0.018 \\
Acetabular inclination (range)* & $46(30-58)$ & $42(30-57)$ & 0.009 \\
Cobalt $(\mu \mathrm{g} / \mathrm{L})^{\dagger}$ & 2.34 & 2.22 & 0.42 \\
Chromium $(\mu \mathrm{g} / \mathrm{L})^{\dagger}$ & 0.78 & 0.51 & 0.29 \\
Molybdenum $(\mu \mathrm{g} / \mathrm{L})^{\dagger}$ & 1.86 & 1.59 & 0.052 \\
Total antioxidants $(\mathrm{mM})^{*}$ & 503 & 517 & 0.86 \\
Peroxide $(\mathrm{nmol} / \mathrm{mL})^{*}$ & 455 & 406 & 0.22 \\
Nitrotyrosine $(\mathrm{nM})^{\dagger}$ & 7.5 & 8.2 & 0.56 \\
\hline
\end{tabular}

* These values are given as the mean at 1 year; ${ }^{\dagger}$ these values are given as the median at 1 year.

Table 3. Effect of inclination and anteversion on metal ion levels

\begin{tabular}{llll}
\hline Femoral head size & Ion & \multicolumn{2}{l}{ Inclination } \\
\cline { 3 - 4 } & & Correlation & $\mathrm{p}$ Value \\
\hline Small head & Co & -0.205 & 0.21 \\
& $\mathrm{Cr}$ & -0.055 & 0.74 \\
Large head & Mo & -0.102 & 0.54 \\
& Co & -0.189 & 0.21 \\
& Cr & -0.239 & 0.11 \\
Small head & Mo & -0.11 & 0.47 \\
& & Anteversion & \\
Large head & Co & -0.106 & 0.53 \\
& Cr & -0.17 & 0.3 \\
& Mo & -0.016 & 0.93 \\
& Co & 0.124 & 0.41 \\
& Cr & 0.346 & 0.017 \\
& Mo & 0.281 & 0.075 \\
\hline
\end{tabular}

Co = cobalt Cr $=$ chromium; Mo = molybdenum.

$42.0^{\circ}$, respectively). The mean acetabular anteversion was also increased $(\mathrm{p}=0.018)$ in the small femoral head group (mean $25.5^{\circ}$ versus $20.0^{\circ}$ ) (Table 2 ). The acetabular inclination was not related to the levels of cobalt, chromium, and molybdenum in patients with both small and large head THA (Table 3). The anteversion was also not correlated with the levels of cobalt, chromium, or molybdenum in patients with small head THA. However, larger anteversion increased the levels of chromium (correlation $=$ 0.346, $\mathrm{p}=0.017$ ) and tended to increase the levels of molybdenum (correlation $=0.281, \mathrm{p}=0.075)$ (Table 3$)$. Finally, the surgical approach (direct lateral versus posterior; $\mathrm{p}=0.11,0.15,0.13$ for $\mathrm{Co}, \mathrm{Cr}$, and $\mathrm{Mo}$, respectively) and the type of stem $(p=0.16,0.25$, and 0.40 for $\mathrm{Co}, \mathrm{Cr}$, and $\mathrm{Mo}$, respectively, with Prodigy stem; $\mathrm{p}=$ $0.83,0.13$, and 0.75 for $\mathrm{Co}, \mathrm{Cr}$, and Mo, respectively, with the other stems) did not influence the levels of metal ions in patients with both small and large head THA. However, all outlier measurements, arbitrarily fixed at more than
$10 \mu \mathrm{g} / \mathrm{L}$ of cobalt, were in patients who had their surgery performed through a posterior approach. Also, the concentrations of cobalt ions in the small head outlier group (three patients; maximum of $19 \mu \mathrm{g} / \mathrm{L}$ ) were lower than those observed in patients with large head THA (eight patients; three patients over $40 \mu \mathrm{g} / \mathrm{L})$.

\section{Discussion}

Hard-on-hard bearings such as those composed of cobalt, chromium, and molybdenum are promoted to increase implant longevity by decreasing volumetric wear rates $[1,12,44]$. This is an attractive surgical option for use in younger, more active patients. To minimize wear, classic elastohydrodynamic theory suggests wear reduction for larger diameter head bearings [18]. However, the survival of these larger head implants and the levels of metal ions in the blood of patients with these implants remain to be determined. Larger femoral heads have the advantage of increased range of motion and stability [8, 9]. There have been studies analyzing the head diameter with ion concentrations but have not uniformly examined patients with THA and femoral head diameters above $40 \mathrm{~mm}[2,14,16$, $24,42,54]$. The purposes of our study were to (1) determine if there was a change in whole blood cobalt and chromium ion concentrations in patients with small (28 $\mathrm{mm}$ and $36 \mathrm{~mm}$ ) and large (40 $\mathrm{mm}$ and $44 \mathrm{~mm}$ ) diameter femoral heads after THA; (2) measure oxidative stress markers (total antioxidants, nitrotyrosine, and peroxides) to determine if the increased metal ions altered the body's oxidant status; and (3) determine whether acetabular version or inclination influenced ion levels.

This study has some limitations. First, it was not a randomized controlled trial comparing varying femoral head sizes while keeping all other parameters constant. However, randomization was not possible given the limitations on femoral head size enforced by acetabular geometry. Because of the absence of randomization, the 
two groups we compared were not age- and gendermatched. This is also inherent in the anatomy, because smaller femoral head diameters are usually placed in women. However, the groups had similar UCLA activity scores; this is probably more important than the observed differences, because wear is mainly a function of use [47] and considering two studies [38] have reported a mild (10\%-13\%) increase in cobalt but not chromium after exercise. Second, we considered the 36- $\mathrm{mm}$ diameter femoral heads as small. However, we seldom used a 28$\mathrm{mm}$ head in our patients. Therefore, for the purpose of this study we required a comparative group and wanted to explore the potential wear advantage of heads larger than $40 \mathrm{~mm}$. We have already demonstrated that at 1 year, there is no difference in metal ion release between the 36- and 28-mm diameter heads [2]. Third, the femoral heads were not all from the same manufacturer. However, the Metasul heads were only used in the six patients with head diameters of $28 \mathrm{~mm}$. Furthermore, both heads are forged, wrought, high-carbon cobalt-chrome alloy components with similar radial clearances. Fourth, because our study was not prospectively designed, we lack preoperative metal ion concentrations. We cannot comment on baseline values nor can we compare preoperative values with those at 1 year to examine any trends. Our metal ion values at 1 year in well-functioning hips are similar to the other studies $[2,16,54]$ and can potentially contribute to establishing a threshold for metal ion levels. Fifth, we have used metal ion analysis as a surrogate for wear. This is consistent with several authors that suggested increased systemic levels of cobalt and chromium may be accurate for wear in metal-on-metal hip arthroplasty [20], because radiographic evidence of wear is less accurate with modern metalon-metal articulations [7, 35, 42]. This assumption may be accurate because most of the wear debris in metal-on-metal articulations should theoretically arise from the bearing surfaces [35]. However, there is still conflicting evidence in the literature to suggest serum or whole blood levels of cobalt and chromium can accurately reflect wear. Moreover, there are reports of patients with major increases in metal ion levels without any clinical or radiographic signs of failure [35]. This suggests efficient ion excretion may influence the level of metal ions in blood. Although not well defined in the literature, these patient parameters can be responsible, in part, for the observed outlier values. This remains to be investigated.

We observed no difference in cobalt, chromium, or molybdenum concentrations at 1 year when comparing small (28 $\mathrm{mm}$ and $36 \mathrm{~mm})$ with large $(40 \mathrm{~mm}$ and $44 \mathrm{~mm})$ diameter femoral heads after metal-on-metal THA. This is consistent with a previous study that also showed no change in whole blood metal ion concentrations in patients who had a $28-\mathrm{mm}$ or 36-mm metal-on-metal THA implanted [2] (Table 4). More recently, a randomized controlled trial comparing patients after $28-\mathrm{mm}$ metalon-metal THA or hip resurfacing also failed to show a difference in whole blood metal ion concentrations [54]. The authors compared the Metasul (Zimmer) articulation with Durom (Zimmer) hip resurfacing, which have radial clearances of $45 \mu \mathrm{m}$ and $75 \mu \mathrm{m}$, respectively. Tribologic theory and hip simulator studies suggest mixed-fluid film lubrication occurs with larger femoral head diameters and decreasing radial clearances [12, 22, 51]. The lack of metal ion release in their study may have resulted from offsetting the decreasing clearances with smaller diameter femoral heads. Another randomized control trial compared large head metal-on-metal THA with hip resurfacing [24]. The authors found a 10-fold increase in cobalt and 2.6-fold increase in chromium in the patients who received the large head THA. This study failed to identify the radial clearance of the femoral heads in the two groups. Conversely, Clarke et al. observed a decrease in cobalt and chromium ions in patients 16 months after a 28-mm metal-on-metal THA compared with hip resurfacing (mean femoral head diameter $48 \mathrm{~mm}$ ) [14]. The authors suggested the decrease in the smaller femoral head group was the result of more resistance to microseparation. The authors measured the mean metal ion concentrations in serum and explained the limitation of comparing within the literature [3, 57]. Indeed, Daniel et al. published whole blood ion values that failed to show a difference between patients 2 years after hip resurfacing with either $50-\mathrm{mm}$ or $54-\mathrm{mm}$ femoral head diameters and 28-mm diameter metal-on-metal THA [16]. Sources of conflicting data in the literature can be explained in part by variations in sampling methods and metal ion analysis. Comparative studies often contrast bearings with different radial clearances or include patients after hip resurfacing that do not contain modular components like those found in THA articulations. The Morse taper can serve as a source of ions and may influence the measured metal ion concentrations [36]. Further studies that use the same sampling methods and implants in patients that are matched for body mass index, age, and gender should be performed before the final verdict can be made regarding the role of metal-on-metal articulations.

There is ongoing concern regarding cellular toxicity $[17,32,50]$, Type IV hypersensitivity reactions $[18,45$, 55], and altered immunoregulatory mechanisms [26, 27, $30,31]$ resulting from chronic systemic elevations of metal ions in this patient population. Metal ions can generate the formation of free radicals [52]. Subsequently, DNA and other cellular constituents such as lipids and proteins are damaged when the antioxidants are consumed [53]. Our results demonstrate the levels of oxidative stress markers (total antioxidants, nitrotyrosine, and peroxides) were similar in patients with small and large femoral head THA. 
Table 4. Recent literature review of metal ion concentrations comparing femoral head diameter in metal-on-metal arthroplasty

\begin{tabular}{|c|c|c|c|c|c|}
\hline Authors & Head sizes (range) & Arthroplasty & Manufacturer & $\begin{array}{l}\text { Metal ion results, } \\
\text { whole blood, } \mu \mathrm{g} / \mathrm{L} \text { (range) }\end{array}$ & $\mathrm{p}$ Value \\
\hline Antoniou et al. [2] & $36 \mathrm{~mm}$ & THA & Ultamet & $\begin{array}{l}\text { Cr } 0.4 \\
\text { Co } 2.3\end{array}$ & $>0.2, \mathrm{Cr}$ \\
\hline Followup at 12 months & $28 \mathrm{~mm}$ & THA & Metasul & $\begin{array}{l}\text { Cr } 0.6 \\
\text { Co } 2.6\end{array}$ & $>0.15, \mathrm{Co}$ \\
\hline Clarke et al. [14] & $\begin{array}{l}48 \mathrm{~mm} \\
\quad \text { (range, } 38-54 \mathrm{~mm})\end{array}$ & Resurfacing & $\begin{array}{l}\text { BHR } \\
\text { Cormet }\end{array}$ & $\begin{array}{l}* \operatorname{Cr} 53(25-165) \\
* \operatorname{Co~} 38(14-44)\end{array}$ & $0.0001, \mathrm{Cr}$ \\
\hline $\begin{array}{l}\text { Median followup } 16 \text { months } \\
\text { (range, } 7-56 \text { months) }\end{array}$ & $28 \mathrm{~mm}$ & THA & Ultima & $\begin{array}{l}* \text { Cr } 19(2-58) \\
* \text { Co } 22(15-87\end{array}$ & $0.0021, \mathrm{Co}$ \\
\hline Daniel et al. [16] & 50 and $54 \mathrm{~mm}$ & Resurfacing & BHR & $\begin{array}{l}\text { Cr } 1.3 \\
\text { Co } 2.4\end{array}$ & $0.055, \mathrm{Cr}$ \\
\hline Mean followup 12 months & $28 \mathrm{~mm}$ & THA & Metasul & $\begin{array}{l}\text { Cr } 1.7 \\
\text { Co } 1.7\end{array}$ & 0.28, Co \\
\hline Langton et al. [42] & $\leq 51 \mathrm{~mm}$ & Resurfacing & ASR & $\begin{array}{l}\text { Cr } 4.12(1.5-70) \\
\text { Co } 2.43(0.48-271)\end{array}$ & $0.004, \mathrm{Cr}$ \\
\hline Mean followup 26 months & $\geq 53 \mathrm{~mm}$ & Resurfacing & ASR & $\begin{array}{l}\text { Cr } 3.04(1.5-5.5) \\
\text { Co } 1.48(0.4-5.6)\end{array}$ & 0.007, Co \\
\hline Vendittoli et al. [54] & $\begin{array}{l}48.8 \mathrm{~mm} \\
\quad(\text { range, } 40-58 \mathrm{~mm})\end{array}$ & Resurfacing & Durom & $\begin{array}{l}\text { Cr } 1.58 \\
\text { Co } 0.67\end{array}$ & $0.819, \mathrm{Cr}$ \\
\hline Followup at 24 months & $28 \mathrm{~mm}$ & THA & Metasul & $\begin{array}{l}\text { Cr } 1.62 \\
\text { Co } 0.94\end{array}$ & 0.207, Co \\
\hline Bernstein et al. [current study] & 40 and $44 \mathrm{~mm}$ & THA & Ultamet & $\begin{array}{l}\text { Cr } 0.51 \\
\text { Co } 2.22\end{array}$ & $0.29, \mathrm{Cr}$ \\
\hline Followup at 12 months & 28 and $36 \mathrm{~mm}$ & THA & $\begin{array}{l}\text { Ultamet } \\
\text { Metasul }\end{array}$ & $\begin{array}{l}\text { Cr } 0.78 \\
\text { Co } 2.34\end{array}$ & 0.42 , Co \\
\hline
\end{tabular}

* Metal ions analyzed from serum (nmol/L); BHR = Birmingham Hip Resurfacing; ASR = Articular Surface Replacement; Cr = chromium; Co $=$ cobalt.

This suggests the increase in metal ion load does not alter the body's systemic antioxidant status. The correlation between increased oxidative stress markers and adverse local soft tissue reactions still needs to be confirmed.

We observed differing mean acetabular inclination and version between the small and large femoral head groups. However, all means, other than anteversion in the small femoral head group, were in the so-called "safe-zone" of Lewinnek et al. [43] and below the published threshold of acetabular inclination for increased metal ions [7, 19, 29]. In addition, the acetabular inclination and version had little or no effect on the levels of cobalt, chromium, and molybdenum. We cannot explain the relationship between acetabular position and the size of the femoral head. The data also demonstrated acetabular inclination had no effect on metal ion levels in patients with both small and large femoral head THA. Acetabular anteversion was positively correlated only with the concentration of chromium ions in the large femoral head group.

In summary, metal-on-metal bearings in THA generated similar levels of whole blood cobalt, chromium, and molybdenum ions when comparing small (28 and $36 \mathrm{~mm}$ ) with large (40 and $44 \mathrm{~mm}$ ) femoral heads. We found similar HHS and UCLA activity scores and levels of cobalt, chromium, and molybdenum at 1 year postoperatively in patients with small and large femoral head metal-on-metal THA. Longer followup studies and close monitoring of patients with metal-on-metal bearings are warranted owing to ongoing concerns about potential complications from chronic elevations in metal ions.

Acknowledgments We thank Maricar Alminia and Laura Des Rosiers for their help in administration of the questionnaires and recording the clinical data.

\section{References}

1. Anissian HL, Stark A, Gustafson A, Good V, Clarke IC. Metalon-metal bearing in hip prosthesis generates 100-fold less wear debris than metal-on-polyethylene. Acta Orthop Scand. 1999;70:578-582.

2. Antoniou J, Zukor DJ, Mwale F, Minarik W, Petit A, Huk OL. Metal ion levels in the blood of patients after hip resurfacing: 
a comparison between twenty-eight and thirty-six-millimeterhead metal-on-metal prostheses. J Bone Joint Surg Am. 2008; 90(Suppl 3):142-148.

3. Back DL, Young DA, Shimmin AJ. How do serum cobalt and chromium levels change after metal-on-metal hip resurfacing? Clin Orthop Relat Res. 2005;438:177-181.

4. Beckman JS, Koppenol WH. Nitric oxide, superoxide, and peroxynitrite: the good, the bad, and ugly. Am J Physiol. 1996;271: C1424-1437.

5. Berger RA, Jacobs JJ, Quigley LR, Rosenberg AG, Galante JO. Primary cementless acetabular reconstruction in patients younger than 50 years old. 7- to 11-year results. Clin Orthop Relat Res. 1997;344:216-226

6. Brodner W, Grohs JG, Bitzan P, Meisinger V, Kovarik J, Kotz R. Serum cobalt and serum chromium level in 2 patients with chronic renal failure after total hip prosthesis implantation with metal-metal gliding contact [in German]. Z Orthop Ihre Grenzgeb. 2000;138:425-429.

7. Brodner W, Grubl A, Jankovsky R, Meisinger V, Lehr S, Gottsauner-Wolf F. Cup inclination and serum concentration of cobalt and chromium after metal-on-metal total hip arthroplasty. J Arthroplasty. 2004;19:66-70.

8. Burroughs BR, Hallstrom B, Golladay GJ, Hoeffel D, Harris WH. Range of motion and stability in total hip arthroplasty with 28-, 32-, 38-, and 44-mm femoral head sizes. J Arthroplasty. 2005;20:11-19.

9. Burroughs BR, Rubash HE, Harris WH. Femoral head sizes larger than $32 \mathrm{~mm}$ against highly cross-linked polyethylene. Clin Orthop Relat Res. 2002;405:150-157.

10. Case CP, Ellis L, Turner JC, Fairman B. Development of a routine method for the determination of trace metals in whole blood by magnetic sector inductively coupled plasma mass spectrometry with particular relevance to patients with total hip and knee arthroplasty. Clin Chem. 2001;47:275-280.

11. Case CP, Langkamer VG, Lock RJ, Perry MJ, Palmer MR, Kemp AJ. Changes in the proportions of peripheral blood lymphocytes in patients with worn implants. J Bone Joint Surg Br. 2000;82: 748-754.

12. Chan FW, Bobyn JD, Medley JB, Krygier JJ, Tanzer M. The Otto Aufranc Award. Wear and lubrication of metal-on-metal hip implants. Clin Orthop Relat Res. 1999;369:10-24.

13. Chan FW, Bobyn JD, Medley JB, Krygier JJ, Yue S, Tanzer M. Engineering issues and wear performance of metal on metal hip implants. Clin Orthop Relat Res. 1996;333:96-107.

14. Clarke MT, Lee PT, Arora A, Villar RN. Levels of metal ions after small- and large-diameter metal-on-metal hip arthroplasty. J Bone Joint Surg Br. 2003;85:913-917.

15. Daniel J, Ziaee H, Pynsent PB, McMinn DJ. The validity of serum levels as a surrogate measure of systemic exposure to metal ions in hip replacement. J Bone Joint Surg Br. 2007;89: 736-741.

16. Daniel J, Ziaee H, Salama A, Pradhan C, McMinn DJ. The effect of the diameter of metal-on-metal bearings on systemic exposure to cobalt and chromium. J Bone Joint Surg Br. 2006;88:443-448.

17. Davies AP, Sood A, Lewis AC, Newson R, Learmonth ID, Case CP. Metal-specific differences in levels of DNA damage caused by synovial fluid recovered at revision arthroplasty. J Bone Joint Surg Br. 2005;87:1439-1444.

18. Davies AP, Willert HG, Campbell PA, Learmonth ID, Case CP. An unusual lymphocytic perivascular infiltration in tissues around contemporary metal-on-metal joint replacements. J Bone Joint Surg Am. 2005;87:18-27.

19. De Haan R, Pattyn C, Gill HS, Murray DW, Campbell PA, De Smet K. Correlation between inclination of the acetabular component and metal ion levels in metal-on-metal hip resurfacing replacement. J Bone Joint Surg Br. 2008;90:1291-1297.
20. De Smet K, De Haan R, Calistri A, Campbell PA, Ebramzadeh E, Pattyn C, Gill HS. Metal ion measurement as a diagnostic tool to identify problems with metal-on-metal hip resurfacing. J Bone Joint Surg Am. 2008;90(Suppl 4):202-208.

21. Doorn PF, Campbell PA, Worrall J, Benya PD, McKellop HA, Amstutz HC. Metal wear particle characterization from metal on metal total hip replacements: transmission electron microscopy study of periprosthetic tissues and isolated particles. J Biomed Mater Res. 1998;42:103-111.

22. Dowson D. New joints for the Millennium: wear control in total replacement hip joints. Proc Inst Mech Eng H. 2001;215: 335-358.

23. Engh CA Jr, Claus AM, Hopper RH Jr, Engh CA. Long-term results using the anatomic medullary locking hip prosthesis. Clin Orthop Relat Res. 2001;393:137-146.

24. Garbuz DS, Tanzer M, Greidanus NV, Masri BA, Duncan CP. The John Charnley Award: metal-on-metal hip resurfacing versus large-diameter head metal-on-metal total hip arthroplasty: a randomized clinical trial. Clin Orthop Relat Res. 2010;468: 318-325.

25. Goldberg JR, Gilbert JL, Jacobs JJ, Bauer TW, Paprosky W, Leurgans S. A multicenter retrieval study of the taper interfaces of modular hip prostheses. Clin Orthop Relat Res. 2002;401:149-161.

26. Hallab NJ, Anderson S, Caicedo M, Skipor A, Campbell P, Jacobs JJ. Immune responses correlate with serum-metal in metal-on-metal hip arthroplasty. J Arthroplasty. 2004;19:88-93.

27. Hallab NJ, Caicedo M, Finnegan A, Jacobs JJ. Th1 type lymphocyte reactivity to metals in patients with total hip arthroplasty. J Orthop Surg. 2008;3:6.

28. Harris WH. Traumatic arthritis of the hip after dislocation and acetabular fractures: treatment by mold arthroplasty. An endresult study using a new method of result evaluation. J Bone Joint Surg Am. 1969;51:737-755.

29. Hart AJ, Buddhdev P, Winship P, Faria N, Powell JJ, Skinner JA. Cup inclination angle of greater than 50 degrees increases whole blood concentrations of cobalt and chromium ions after metal-onmetal hip resurfacing. Hip Int. 2008;18:212-219.

30. Hart AJ, Hester T, Sinclair K, Powell JJ, Goodship AE, Pele L, Fersht NL, Skinner J. The association between metal ions from hip resurfacing and reduced T-cell counts. J Bone Joint Surg Br. 2006;88:449-454.

31. Hart AJ, Skinner JA, Winship P, Faria N, Kulinskaya E, Webster $\mathrm{D}$, Muirhead-Allwood S, Aldam $\mathrm{CH}$, Anwar $\mathrm{H}$, Powell JJ. Circulating levels of cobalt and chromium from metal-on-metal hip replacement are associated with $\mathrm{CD} 8+\mathrm{T}$-cell lymphopenia. J Bone Joint Surg Br. 2009;91:835-842.

32. Huk OL, Catelas I, Mwale F, Antoniou J, Zukor DJ, Petit A. Induction of apoptosis and necrosis by metal ions in vitro. J Arthroplasty. 2004;19:84-87.

33. Hur CI, Yoon TR, Cho SG, Song EK, Seon JK. Serum ion level after metal-on-metal THA in patients with renal failure. Clin Orthop Relat Res. 2008;466:696-699.

34. Iida H, Kaneda E, Takada H, Uchida K, Kawanabe K, Nakamura $\mathrm{T}$. Metallosis due to impingement between the socket and the femoral neck in a metal-on-metal bearing total hip prosthesis. A case report. J Bone Joint Surg Am. 1999;81:400-403.

35. Jacobs JJ, Skipor AK, Campbell PA, Hallab NJ, Urban RM, Amstutz HC. Can metal levels be used to monitor metal-on-metal hip arthroplasties. J Arthroplasty. 2004;19:59-65.

36. Jacobs JJ, Skipor AK, Doorn PF, Campbell P, Schmalzried TP, Black J, Amstutz HC. Cobalt and chromium concentrations in patients with metal on metal total hip replacements. Clin Orthop Relat Res. 1996;329(Suppl):S256-263.

37. Jacobs JJ, Urban RM, Gilbert JL, Skipor AK, Black J, Jasty M, Galante JO. Local and distant products from modularity. Clin Orthop Relat Res. 1995;319:94-105. 
38. Khan M, Takahashi T, Kuiper JH, Sieniawska CE, Takagi K, Richardson JB. Current in vivo wear of metal-on-metal bearings assessed by exercise-related rise in plasma cobalt level. J Orthop Res. 2006;24:2029-2035.

39. Kim YH, Oh SH, Kim JS. Primary total hip arthroplasty with a second-generation cementless total hip prosthesis in patients younger than fifty years of age. J Bone Joint Surg Am. 2003;85: 109-114.

40. Kothari M, Bartel DL, Booker JF. Surface geometry of retrieved McKee-Farrar total hip replacements. Clin Orthop Relat Res. 1996;329(Suppl):S141-147.

41. Krismer M, Bauer R, Tschupik J, Mayrhofer P. EBRA: a method to measure migration of acetabular components. J Biomech. 1995;28:1225-1236.

42. Langton DJ, Jameson SS, Joyce TJ, Webb J, Nargol AV. The effect of component size and orientation on the concentrations of metal ions after resurfacing arthroplasty of the hip. J Bone Joint Surg Br. 2008;90:1143-1151.

43. Lewinnek GE, Lewis JL, Tarr R, Compere CL, Zimmerman JR. Dislocations after total hip-replacement arthroplasties. $J$ Bone Joint Surg Am. 1978;60:217-220.

44. McKellop H, Park SH, Chiesa R, Doorn P, Lu B, Normand P, Grigoris $\mathrm{P}$, Amstutz H. In vivo wear of three types of metal on metal hip prostheses during two decades of use. Clin Orthop Relat Res. 1996;329(Suppl):S128-140.

45. Pandit H, Glyn-Jones S, McLardy-Smith P, Gundle R, Whitwell D, Gibbons CL, Ostlere S, Athanasou N, Gill HS, Murray DW. Pseudotumours associated with metal-on-metal hip resurfacings. J Bone Joint Surg Br. 2008;90:847-851.

46. Rae T. A study on the effects of particulate metals of orthopaedic interest on murine macrophages in vitro. J Bone Joint Surg Br. 1975;57:444-450.

47. Schmalzried TP, Huk OL. Patient factors and wear in total hip arthroplasty. Clin Orthop Relat Res. 2004;418:94-97.
48. Schmalzried TP, Peters PC, Maurer BT, Bragdon CR, Harris WH. Long-duration metal-on-metal total hip arthroplasties with low wear of the articulating surfaces. J Arthroplasty. 1996;11: 322-331.

49. Schmalzried TP, Shepherd EF, Dorey FJ, Jackson WO, dela Rosa M, Fa'vae F, McKellop HA, McClung CD, Martell J, Moreland JR, Amstutz HC. The John Charnley Award. Wear is a function of use, not time. Clin Orthop Relat Res. 2000;381:36-46.

50. Shanbhag AS, Jacobs JJ, Black J, Galante JO, Glant TT. Human monocyte response to particulate biomaterials generated in vivo and in vitro. J Orthop Res. 1995;13:792-801.

51. Smith SL, Dowson D, Goldsmith AA. The effect of femoral head diameter upon lubrication and wear of metal-on-metal total hip replacements. Proc Inst Mech Eng H. 2001;215:161-170.

52. Stohs SJ, Bagchi D. Oxidative mechanisms in the toxicity of metal ions. Free Radic Biol Med. 1995;18:321-336.

53. Therond P, Bonnefont-Rousselot D, Davit-Spraul A, Conti M, Legrand A. Biomarkers of oxidative stress: an analytical approach. Curr Opin Clin Nutr Metab Care. 2000;3:373-384.

54. Vendittoli PA, Roy A, Mottard S, Girard J, Lusignan D, Lavigne M. Metal ion release from bearing wear and corrosion with $28 \mathrm{~mm}$ and large-diameter metal-on-metal bearing articulations: a follow-up study. J Bone Joint Surg Br. 2010;92:12-19.

55. Willert HG, Buchhorn GH, Fayyazi A, Flury R, Windler M, Koster G, Lohmann CH. Metal-on-metal bearings and hypersensitivity in patients with artificial hip joints. A clinical and histomorphological study. J Bone Joint Surg Am. 2005;87:28-36.

56. Zahiri CA, Schmalzried TP, Szuszczewicz ES, Amstutz HC. Assessing activity in joint replacement patients. J Arthroplasty. 1998;13:890-895.

57. Ziaee H, Daniel J, Datta AK, Blunt S, McMinn DJ. Transplacental transfer of cobalt and chromium in patients with metalon-metal hip arthroplasty: a controlled study. J Bone Joint Surg Br. 2007;89:301-305. 